\title{
Analisis dan Perancangan Proses Purchase Order pada PT. Cybertrend Intrabuana
}

\author{
Annisa Intan Fadila, Prihatin Oktivasari \\ Jurusan Teknik Informatika \\ Politeknik Negeri Jakarta \\ Depok, Indonesia \\ annisa.fadila@gmail.com, prihatin.oktivasari@tik.pnj.ac.id
}

Diterima: 3 Maret 2015. Disetujui: 8 April 2015. Dipublikasikan: Mei 2015

\begin{abstract}
Abstrak - Purchase Order (PO) adalah bukti tertulis dari pembeli kepada penjual yang secara sungguh-sungguh berminat melakukan pembelian dengan adanya keterangan secara rinci mengenai barang yang akan dibeli. PO dibuat supaya memudahkan kontrol perusahaan, karyawan, serta supplier dalam melakukan proses bisnis. PT Cybertrend Intrabuana merupakan salah satu perusahaan yang masih menggunakan sistem secara manual. Perancangan modul PO pada PT Cybertrend Intrabuana berbasis web menggunakan framework codeigniter dan terkoneksi dengan database pada MySQL. MySQL merupakan sistem database yang mudah digunakan dengan performa tinggi dan tidak kompleks untuk setup, dan administrator, sedangkan Codeigniter merupakan sebuah framework pemrograman web dengan menggunakan bahasa PHP yang dapat dijalankan pada berbagai platform. Penggunaan Codeigniter membantu pembuatan modul PO menjadi lebih mudah dan terstruktur.
\end{abstract}

Kata Kunci: purchase order, database MySQL, frame work Codeigniter.

\section{PENDAHULUAN}

Sebuah perusahaan dalam seluruh aspek kegiatannya memerlukan supply barang baku ataupun barang jadi. Barang-barang tersebut dibutuhkan agar seluruh kegiatan produksi di suatu perusahaan dapat berjalan dengan lancar. Pada suatu perusahaan kebutuhan akan barang baku ataupun barang jadi umumnya disediakan oleh pihak luar. Pihak luar dalam konteks ini adalah perusahaan penyedia barang-barang tersebut. Untuk mendapatkan berbagai macam barang yang dibutuhkan, perusahaan harus terlebih dahulu melakukan permintaan kepada pihak supplier atau perusahaan penyedia. Dalam proses permintaan barang tersebut perusahaan harus secara rinci menjelaskan barang yang akan dibeli, data perusahaan penerima barang, serta tanggal kirim barang. Proses ini dikenal juga sebagai Purchase
Order (PO). Untuk meningkatkan efisensi dan efektifitas dari kegiatan PO yang dilakukan maka perlu dikembangkan sebuah modul purchase order dalam sistem otomatisasi kantor.

Oleh karena proses PO sangat penting untuk sebuah proses bisnis, maka PT. Cybertrend Intrabuana yang masih menggunakan proses $\mathrm{PO}$ secara manual juga mengembangkan proses $\mathrm{PO}$ berbasis web menggunakan framework Codeigniter supaya lebih efektif dan efisien. Codeigniter menggunakan konsep Model, View, Controller (MVC). MVC memisahkan pengembangan aplikasi berdasarkan komponen utama yang membangun sebuah aplikasi seperti manipulasi data, user interface, dan bagian yang menjadi kontrol aplikasi.

\section{TINJAUAN PUSTAKA}

\section{A. Purchase Order (PO)}

Proses PO yang diajukan harus berdasarkan Purchase Request (PR) atau permintaan pembelian yang sudah disetujui. Proses yang terjadi dalam PO meliputi tawar-menawar untuk pemilihan supplier serta rincian kontrak yang akan dilaksanakan[1]. Penerbitan PO harus sudah sesuai dengan kontrak dan telah ditandatangani oleh pejabat berwenang lalu selanjutnya akan dilakukan proses pengiriman dan konfirmasi oleh pihak supplier. Modul PO adalah modul yang menangani pembuatan PO berdasarkan PR yang sudah ditentukan terakhir yaitu sudah ada pemenang dalam proses tawarmenawar sebelumnya. Dalam modul PO ini tidak diperkenankan melakukan pengubahan item barang, jumlah yang dibeli, spesifikasi, harga, mata uang, dan lain-lain.

Perubahan yang boleh dilakukan di PO adalah perubahan yang tidak ada kaitannya dengan angka PO seperti jangka waktu pembayaran, format pencetakan PO, penggantian supplier, dan lain-lain, karena pemotongan budget hanya ada di modul PR. Jika ingin melakukan pengubahan yang 
berhubungan dengan angka, maka semuanya dilakukan di modul PR dalam hal ini sub modul item PO, jika PR sudah dalam status Accomplished. Proses persetujuan harus dilakukan dalam modul PO meskipun telah mencantumkan angka akhir.

Persetujuan yang dimaksud adalah persetujuan menyangkut isi perjanjian diluar item, harga dan jumlah barang yang dibeli. Karena PO menyangkut pihak luar dalam hal ini supplier maka dibutuhkan bentuk fisik sehingga PO akan melewati proses pencetakan. Maka dari itu proses persetujuan juga meliputi persetujuan menerbitkan PO, harus ada tandatangan fisik terhadap PO yang sudah dicetak.

\section{B. $M Y S Q L$}

MYSQL populer karena mudah untuk digunakan dan kinerjanya yang relatif cepat serta mencukupi kebutuhan database untuk perusahan dengan skala menengah kecil [2]. MySQL sebenarnya merupakan turunan salah satu konsep utama dalam database yang telah ada sebelumnya, yaitu SQL (Structured Query Language). SQL adalah sebuah konsep pengoperasian database, terutama untuk pemilihan atau seleksi dan pemasukan data, yang memungkinkan pengoperasian data dikerjakan dengan mudah secara otomatis, sehingga MySQL adalah sistem database yang mudah digunakan dengan performa tinggi dan tidak kompleks untuk setup, dan administrator.

\section{Codeigneter}

Codeigniter adalah sebuah framework yang digunakan untuk membuat sebuah aplikasi berbasis web yang disusun dengan menggunakan bahasa Hypertext Preprocessor (PHP) [3]. PHP adalah bahasa skript yang dapat disisipkan ke dalam Hyper Text Markup Language (HTML). Pada Codeigniter terdapat beberapa macam kelas yang berbentuk library dan helper yang berfungsi untuk membantu pemrogram dalam mengembangkan aplikasinya. Gambar 1 menggambarkan prinsip kerja framework Codeigniter.

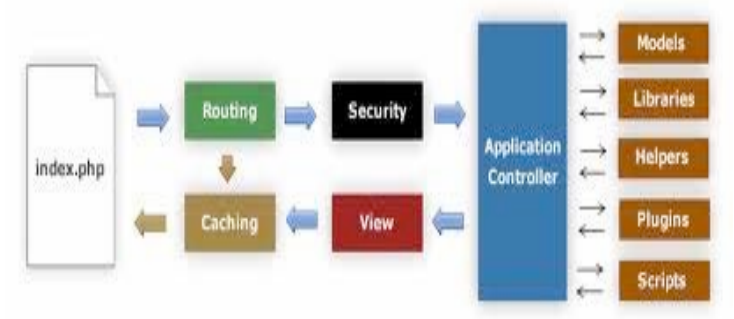

Gambar 1. Prinsip Kerja Framework Codeigniter

Codeigniter menggunakan konsep Model View Controller (MVC). MVC merupakan suatu konsep yang cukup populer dalam pembangunan aplikasi web, berawal pada bahasa pemrograman Small Talk. MVC memisahkan pengembangan aplikasi berdasarkan komponen utama yang membangun sebuah aplikasi seperti manipulasi data, user interface, dan bagian yang menjadi kontrol aplikasi. Terdapat 3 jenis komponen yang membangun suatu MVC pattern dalam suatu aplikasi yaitu view, merupakan bagian yang menangani presentation logic; model, untuk memanipulasi data (insert, update, delete, search) dan menangani validasi dari bagian controller; serta controller, berfungsi untuk menerima permintaan dan data dari user kemudian menentukan apa yang akan diproses oleh aplikasi [4].

\section{METODE PERANCANGAN SISTEM}

Analisa perancangan sistem untuk modul PO ini terbagi dalam beberapa bagian yaitu flowchart, use case diagram, activity diagram, sequence diagram dan Entity Relational Diagram (ERD) [5].

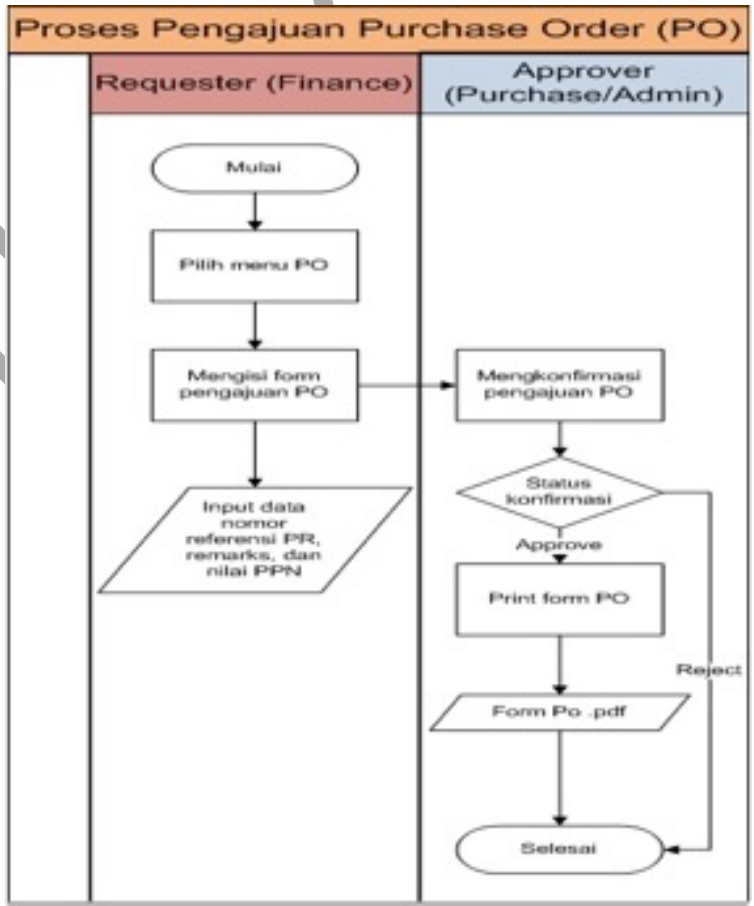

Gambar 2. Flowchart Modul PO

Gambar 2 menggambarkan flowchart dari modul PO. Dalam penggunaan menu PO terdapat tiga aktor yaitu karyawan bagian finance, purchase dan admin. Finance dan purchase memiliki wewenang untuk membuat pengajuan PO, namun hanya purchase dan admin yang dapat melakukan konfirmasi PO apakah nantinya akan di-approve atau di-reject, jika di-approve maka keduanya dapat melakukan print form PO.[6]

Gambar 3 menggambarkan use case diagram dari modul PO dan Gambar 4 menjabarkan activity diagram-nya. 


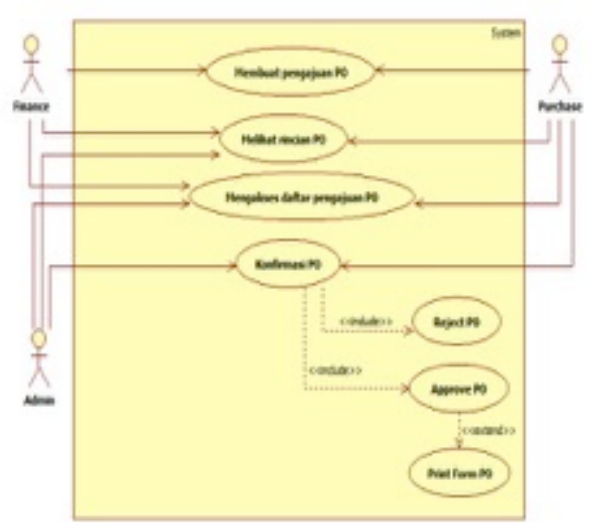

Gambar 3. Use Case Diagram Modul PO

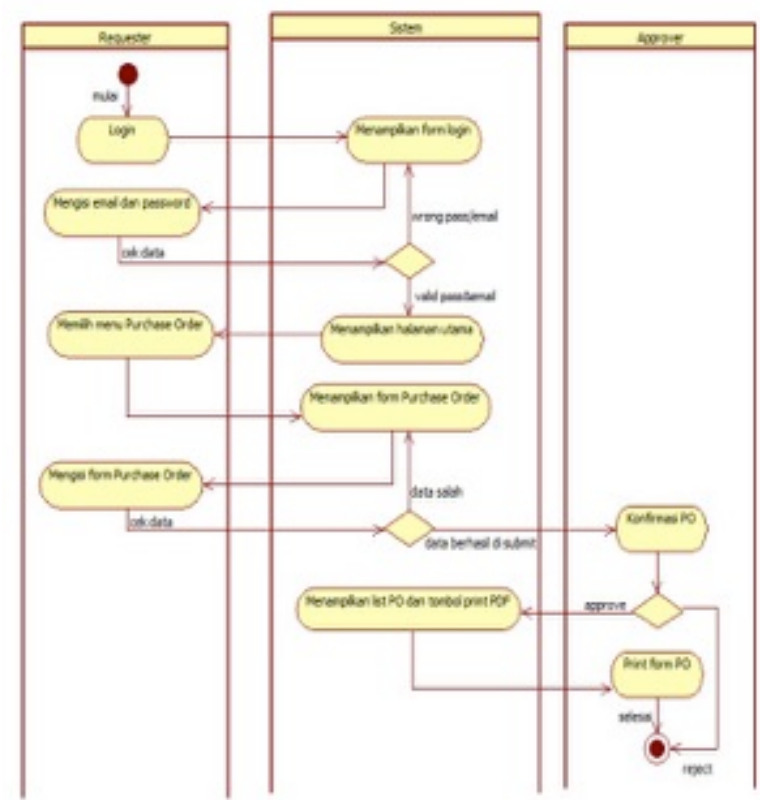

Gambar 4. Activity Diagram Modul PO

Modul pengajuan PO dimulai dari login oleh requester, lalu sistem akan menampilkan form login. Requester kemudian mengisi email dan password untuk login, selanjutnya sistem akan mengecek data tersebut, jika salah akan sistem akan kembali menampilkan form login, jika benar sistem selanjutnya akan menampilkan halaman utama. Setelah itu requester dapat memilih menu purchase order, lalu sistem akan menampilkan form purchase order. Requester kemudian mengisi form purchase order yang tersedia, setelah di-submit sistem akan mengecek data, jika ada data yang salah maka sistem akan menampilkan kembali form purchase order jika data berhasil di-submit maka data tersebut akan dikonfirmasi oleh approver. Saat konfirmasi PO, jika pengajuan tersebut di-reject maka proses selesai jika di-approve maka sistem akan menampilkan list PO dan tombol print PDF, kemudian approver dapat melakukan print PDF form PO tersebut.

Modul pengajuan PO yang terbagi kedalam tiga sequence yaitu login, input data pengajuan PO, dan konfirmasi PO.

\section{Sequence Diagram Login}

Tahapan untuk login dimulai dari requester yang memasukkkan email dan password untuk login kemudian data tersebut akan dicek kebagian control login, setelah divalidasi maka form login tersebut akan tertutup, dan requester akan dialihkan ke halaman utama. Pada halaman utama inilah requester dapat memilih menu PO. Gambar 5 adalah sequence diagram untuk login modul PO.

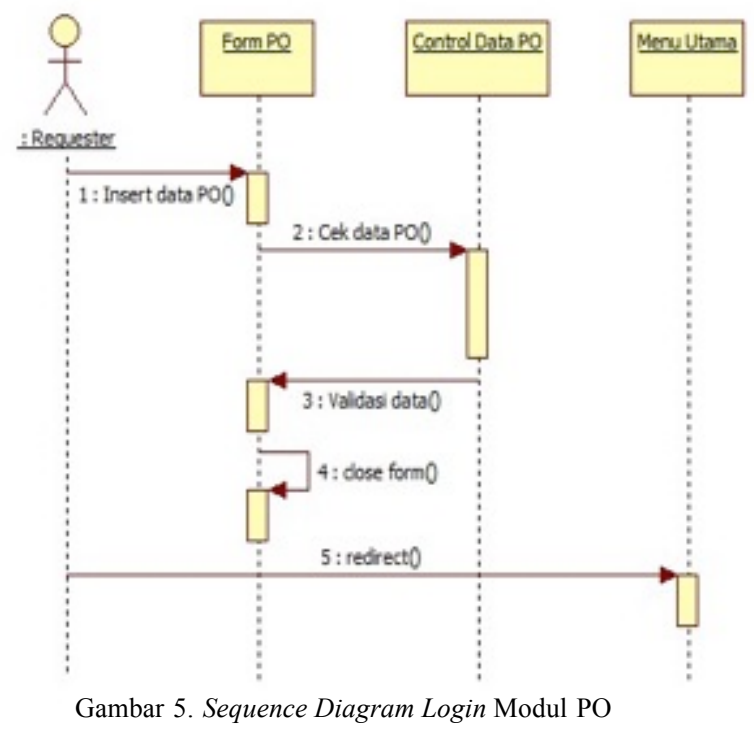

2. Sequence Diagram Input Data Pengajuan PO

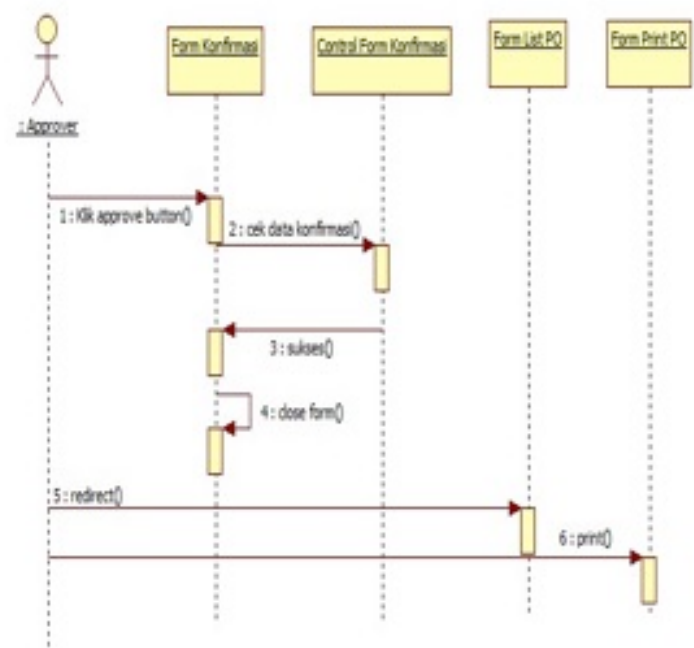

Gambar 6. Sequence Diagram Input Data Pengajuan PO 
Gambar 6 menjabarkan sequence diagram dari proses input data pengajuan PO dimulai saat requester memilih menu $\mathrm{PO}$, lalu memasukkan data PO. Selanjutnya data tersebut akan dicek didalam control data PO, setelah divalidasi maka form PO tersebut akan tertutup lalu requester dialihkan ke menu utama.

\section{Sequence Diagram Konfirmasi PO}

Setelah data PO diajukan maka data tersebut akan dikonfirmasi oleh approver. Konfirmasi PO dimulai saat approver mengklik tombol approver pada halaman konfirmasi, selanjutnya data tersebut akan dicek ke bagian control form konfirmasi, setelah divalidasi maka form konfirmasi akan tertutup, lalu form list PO akan tampil. Selanjutnya approver dapat melakukan print PDF terhadap PO yang telah dikonfirmasi. Gambar 7 adalah gambaran relasi antar tabel untuk pengajuan PO pada ERD.

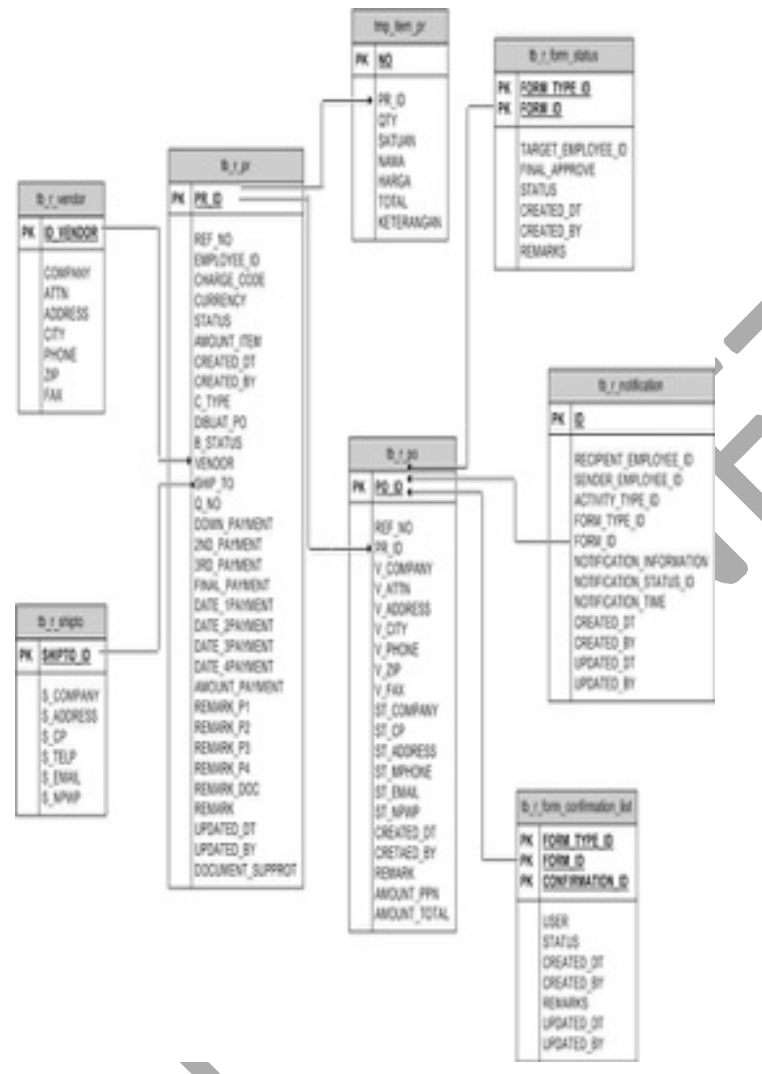

Gambar 7. ERD Database Modul PO

\section{HASIL DAN PEMBAHASAN}

\section{A. Form Pengajuan PO}

Form pengajuan PO seperti pada Gambar 8 dan 9 adalah form yang digunakan oleh finance dalam membuat pengajuan PO berdasarkan nomor referensi PR yang ada. Reference number merupakan elemen penting dalam form ini karena menentukan currency, detail vendor, ship to serta tabel barang.

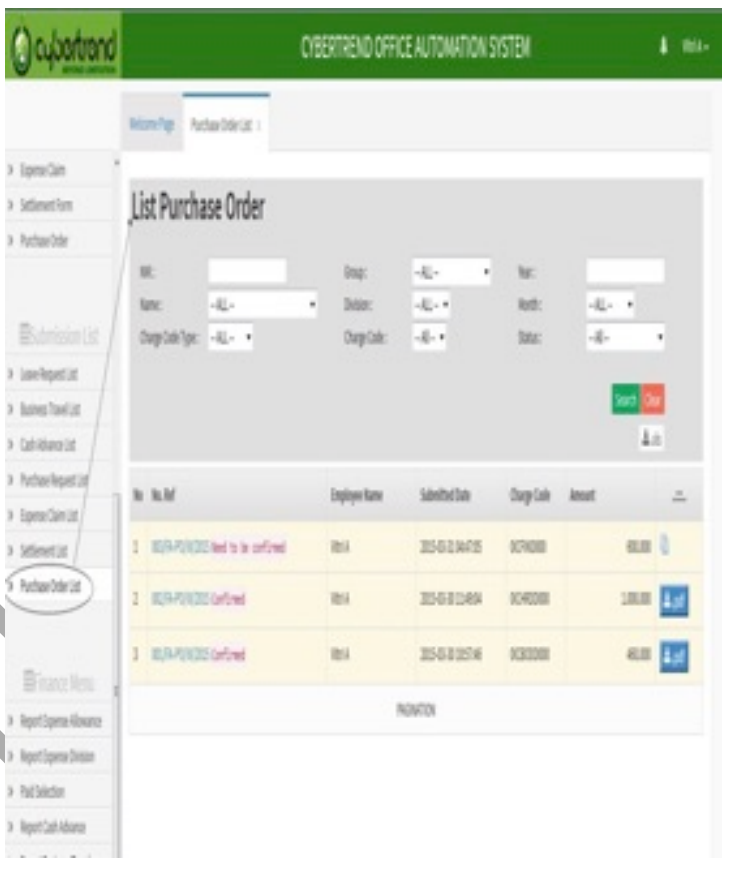

Gambar 8. Tampilan Form PO (1)

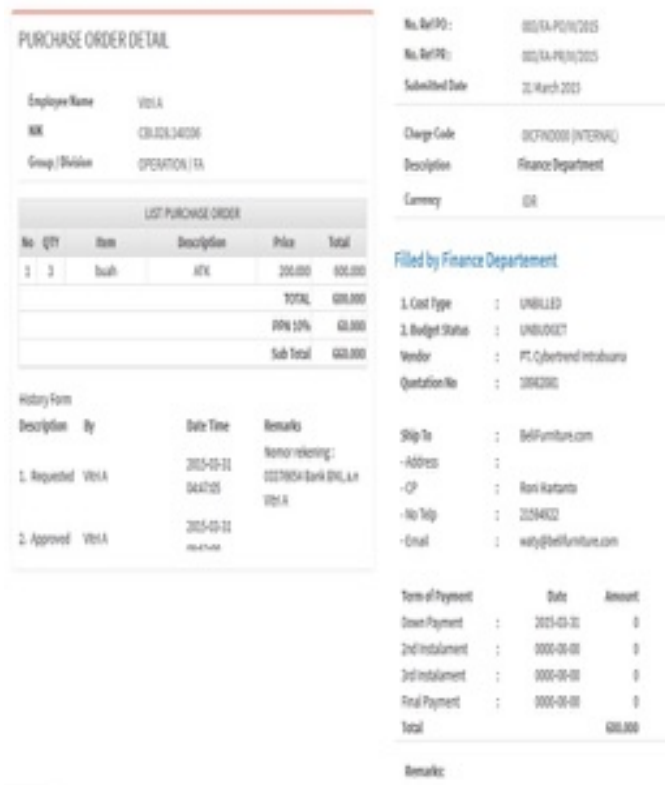

Gambar 9. Tampilan Form PO (2) 


\section{B. Form List PO}

Form List PO seperti terlihat pada Gambar 10 merupakan sebuah form yang berisi daftar PO yang telah diajukan. Dalam form ini terdapat beberapa fitur yaitu pencarian data pengajuan PO dan mengunduh daftar pengajuan PO dalam format .xls. Terdapat beberapa kriteria dalam pencarian data pengajuan $\mathrm{PO}$, yaitu NIK, nama pegawai, charge code, grup, divisi, tahun, bulan, dan status.

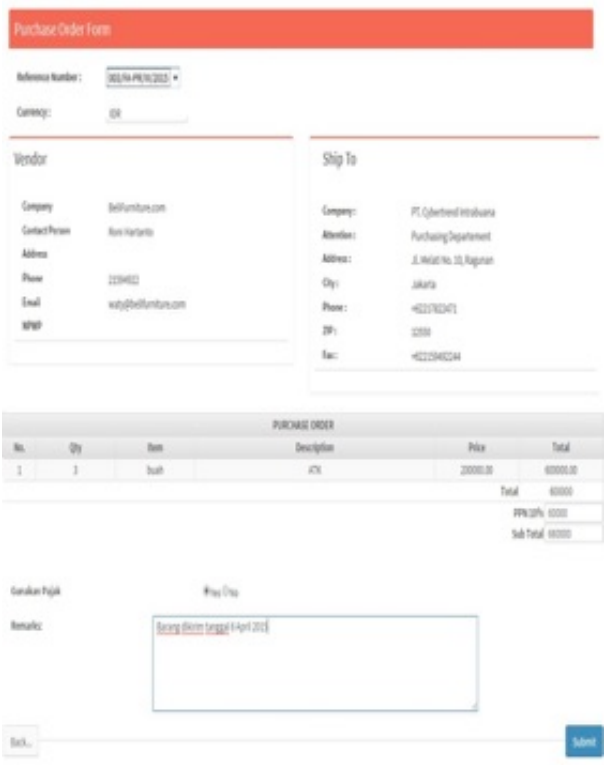

Gambar 10. Tampilan Akhir Form List PO

\section{Form Konfirmasi PO}

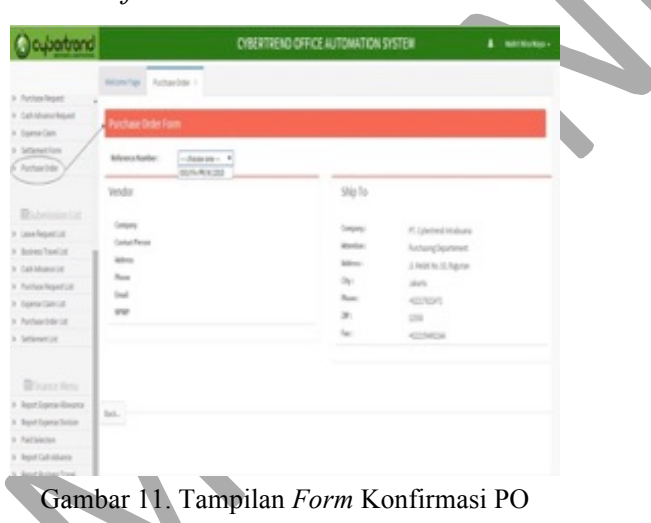

Form konfimasi PO seperti pada Gambar 11 adalah form yang berisikan rincian mengenai PO yang diajukan apakah akan di-approve atau direject oleh approver. Form konfirmasi berisi rincian karyawan yang mengajukan, history form, nomor referensi PR, term of payment, serta data vendor dan ship to.

\section{Form Detail PO}

Form detail PO memiliki konten yang sama dengan form konfirmasi hanya saja dalam form detail tidak terdapat tombol untuk melakukan konfirmasi.

\section{E. Form Print PO}

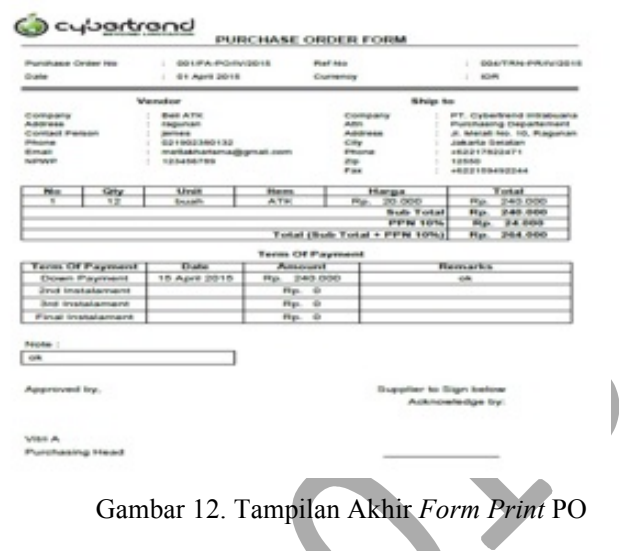

Form print PO seperti pada Gambar 12 adalah form untuk mencetak form PO dalam bentuk PDF yang nantinya akan diberikan serta ditandatangani oleh purchasing head perusahaan dan pihak vendor.

\section{KESIMPULAN DAN SARAN}

Terciptanya modul proses PO pada sistem otomatisasi kantor PT Cybertrend Intrabuana sangat membantu karyawan khususnya dibidang finance dan purchase dalam pengajuan PO sehingga proses bisnis berjalan lebih teratur, perusahaan menjadi lebih mudah dalam mengontrol proses PO yang berjalan dan karyawan dapat lebih efisien dalam membuat form PO serta dapat mempermudah dalam mengelola data-data PO secara lebih baik dibandingkan dengan sistem manual yang digunakan sebelumnya. Penggunaan framework CodeIgniter membantu pembuatan modul PO menjadi lebih mudah dan terstruktur. Mengingat proses bisnis selalu berkembang, maka perlu pengembangan sistem selanjutnya yaitu dengan penambahan fitur-fitur supaya sistem dapat bekerja lebih baik sesuai jamannya.

\section{REFERENSI}

[1] Febriana, Ineke. 2009. Analisis Proses PO (Purchase Order) Pada PT. Kusumahadi Santosa Di Karanganyar.Universitas Sebelas Maret, 38-39.

[2] Betha sidik, Ir. 2005. MySQL. Bandung: Informatika.

[3] Basuki, Awan Pribadi. 2010. Membangun Web Berbasis PHP dengan Framework CodeIgniter. Yogyakarta: Lokomedia.

[4] Haviluddin.2011.Memahami Penggunaan UML.Jurnal Informatika Mulawarman, 2,4,6,8-9.

[5] Hariyanto, Heru Tri.Analisis dan Perancangan Aplikasi Insurance Purchase Order, 31-32.

[6] Prasetyo, Didik Dwi.2003.Tip dan Trik Kolaborasi PHP dan MySQL. Jakarta: PT Alex Media Komputindo. 